\title{
Quality characteristics of Pleurotus eryngii, Lentinus edodes GNA01 and Grifola frondosa as affected by different drying methods
}

\author{
Hee-Jeong Je*, Hyeon Young Kim, Gi-Jeong Ha, Injong ha, Sung Rae Cho \\ Gyeongnam Agricultural Research and Extention Services, Jinju 52733, Korea
}

\section{건조방법에 따른 새송이버섯, 이슬송이버섯, 잎새버섯의 품질 특성}

\author{
제희정*·김현영 · 하기정 · 하인종 · 조성래 \\ 경상남도농업기술원
}

\begin{abstract}
This study compared the quality and drying characteristics of dried king oyster mushroom (Pleurotus eryngii), shiitake mushroom (Lentinus edodes GNA01) and maitake mushroom (Grifola frondosa) slices obtained by sundrying, hot-air drying $\left(40,50,60^{\circ} \mathrm{C}\right)$, low-temperature vacuum drying $\left(20,25,30^{\circ} \mathrm{C}\right)$, heat-pump dehumidifying drying $(30,40$, $50^{\circ} \mathrm{C}$ ), and freeze drying. The quality changes investigted included color, browning degree, hardness, general components, $\beta$-glucan. Color changes in king oyster mushroom during freeze drying were less than that between control (raw) and treated mushrooms. Compared with other drying methods, low-temperature vacuum drying of shiitake mushroom resulted in less color changes. Browning degree differed significantly between the different drying methods. As temperature increased, low-temperature vacuum drying resulted in decreased browning while heat-pump dehumidifying drying resulted in increased browning. In king oyster mushroom, hardness increased with temperature under hot-air drying, low-temperature vacuum drying and heat-pump dehumidifying drying. In shiitake mushroom, hardness increased with increasing temperature under hot-air drying and heat-pump dehumidifying drying. $\beta$-glucan content after drying was found to be between 28.29 and $39.39 \%$ in king oyster mushroom, 23.05 and $29.48 \%$ in shiitake mushroom and 16.10 and $\mathbf{2 4 . 5 1 \%}$ in maitake mushroom.
\end{abstract}

Key words : Pleurotus eryngii, Lentinus edodes GNA01, Grifola frondosa, drying method

\section{서 론}

새송이버섯(Pleurotus eryngii)은 분류학적으로 주름버섯 목(Agaricals), 느타리버섯과(Pleurotaceae), 느타리버섯 속 (Pleurotus)에 속하는 버섯이다(1). 주로 아열대 지방의 건조 성 대초원에서 단생 또는 군생되며 프랑스와 독일, 중앙아 시아, 지중해 연안, 아프리카 북부 등지에 분포하고 있다(2). 새송이버섯은 영양학적 가치가 우수하며 건조물에는 약 $30 \%$ 의 단백질을 함유하고 있어 효과적인 단백질의 공급원

*Corresponding author. E-mail : hity84@korea.kr

Phone : 82-55-254-1874, Fax : 82-55-254-1859

Received 8 January 2018; Revised 5 March 2018; Accepted 15 March 2018.

Copyright (c) The Korean Society of Food Preservation. All rights reserved.
이며 식이섬유 및 각종 비타민과 미네랄 성분을 함유하고 있다(3). 새송이버섯의 소비가 확대되면서 인공재배를 통 한 대량생산이 이루어지고 있으나, 신선한 상태로 장기간 저장이 어려우며 수요 공급의 균형이 적절하게 이루어지지 않아 가격이 폭락하는 등 생산 농가의 피해가 초래된다(4). 일반적으로 새송이버섯은 동결건조방법으로 건조하여 생 식, 이유식 등으로 판매되고 있으며, 생버섯의 소비, 수출은 증대량에 한계가 있고 시중에서 판매되는 버섯가공제품은 건조품 등 주로 단순가공품으로서 버섯의 부가가치 증대, 수출 물량 확대 및 내수소비 촉진 등을 위해 다양한 가공제 품의 개발이 필요하다.

이슬송이버섯(Lentinus edodes GNAI)은 표고버섯(Shiitake mushroom; SM, Lentinus edodes)의 일종으로 중국 복건성 삼명진연구소의 표고버섯 L26과 경원9015를 모균주로 하 여 교배되었으며(5), 갓은 구형으로 자루가 없는 것이 특징 
이다. 이슬송이버섯은 2013년 국제특허등록(제10-1035898) 되었으며(6), 주로 경남지역에서 재배되고 있다. 표고버섯 은 담자균문(basidiomycota), 구멍장이버섯과(Polyporaceae) 잣버섯속(Lentinus), 송이과(Tricholomataceae) 표고속 (Lentinula)에 속하는 버섯으로 세계적으로 생산량과 소비 량이 증가하고 있는 버섯이다. 표고버섯은 항암작용이 있 는 다당류의 일종의 lentinan과 혈중 콜레스테롤의 함량을 저하시키는 eritadenine을 포함하고 있으며 $(7,8)$, 식품영양 학적으로는 탄수화물, 단백질, 지방, 비타민 $\mathrm{B}$, 비타민 $\mathrm{D}$, 다당류, 미네랄 등을 포함하고 있다. 표고버섯은 대부분은 열풍 또는 천일건조 방법에 의해 건조된 후 저장, 유통되고 있다.

잎새버섯(Grifola frondosa)은 분류학적으로 담자균류 민 주름버섯목(Aphyllphorales), 구멍장이버섯과(Polyporaceae), 잎새버섯속(Grifola)에 속하는 버섯으로 여름과 가을에 참 나무류, 활엽수류 생입목, 고사목의 지제부나 뿌리 주변에 다발로 발생하며, 한국, 일본, 유럽, 미국 등에 분포하는 백색부후균이다. 잎새버섯은 식용이면서 약리작용이 뛰어 난 기능성 버섯으로 면역력을 증가시키고(9), 암세포억제, 혈당강하작용, 콜레스테롤 억제작용, 항산화작용 등이 있 는 것으로 알려져 있다(10-13). 잎새버섯은 대부분 열풍건 조하여 건잎새버섯 또는 잎새버섯차로 판매되고 있다.

대부분의 식용버섯의 수분 함량은 85.2-94.7\%로 높으며 (14), 조직이 연하여 신선한 상태를 장기간 유지하기가 어려 워 주로 건조된 상태로 저장, 유통된다. 전통적인 표고버섯 의 건조법은 일광을 이용하였으나 건조기간 동안 일기에 크게 영향을 받을 뿐 아니라 장기간의 건조과정중에 열화현 상이 일어나 중량의 감소와 갈변 및 영양소의 파괴로 인한 품질저하로 열풍건조가 주로 이루어지고 있다. 열풍건조는 신속하고 균일하게 건조가 이루어지며, 다른 건조방법에 비해 경제적이지만, 수분손실에 의한 수축, 빠른 건조에 의한 표면 경화, 건조물의 재수화시 낮은 복원율, 갈색화 반응으로 인한 색상변화, 조직감, 맛 및 영양가를 저하시킨 다(15). 버섯 건조품에서 색상과 질감은 소비자들에게 가장 중요한 품질기준이 되는데(16), 일반적으로 식품을 건조하 면 식품의 색, 질감, 영양 성분 및 생리활성정도에 변화를 초래하게 되므로 건조방법의 확립이 필요하다. 건조된 표 고버섯은 건조과정에서 적당한 열을 가하면 lentinic acid 함량을 증가시켜 생 표고버섯에는 없는 특징적인 냄새를 생성하며(17), 단백질을 아미노산으로 분해하여 감칠맛을 생성함에 따라 많은 소비자들은 건조된 표고버섯을 선호한 다.

따라서 본 연구에서는 고품질의 건조버섯을 얻기 위한 방법으로 다양한 건조방법과 온도처리로 품질을 향상시키 는 방법을 찾고 또한 품질특성 조사를 통하여 이를 이용한 가공제품 제조의 기초자료로 제시하고자 한다.

\section{재료 및 방법}

\section{실험재료}

본 실험에 사용된 새송이버섯은 경남 진주 농가에서 2014년 4월경에 수확한 것을 구입하였으며, 이슬송이버섯, 잎새버섯은 경남 창원 농가에서 같은 시기에 구입하여 즉시 $5 \mathrm{~mm}$ 정도 슬라이스 후 건조하였다.

\section{건조방법}

건조는 천일건조, 열풍건조, 진공저온건조, 히트펌프제 습건조 및 동결건조를 하였다. 천일건조는 일광을 이용하 여 평균기온 $18.3^{\circ} \mathrm{C}$,평균습도 $59.7 \%$ 에서 3 일간 일정 수분함 량이 될 때까지 건조하였으며, 열풍건조는 열풍건조기 (HAS-30, DongJin Machine Ind. Co., Seoul, Korea)를 사용하 여 $40^{\circ} \mathrm{C}, 50^{\circ} \mathrm{C}, 60^{\circ} \mathrm{C}$ 에서 건조하였으며, 저온진공건조는 저 온진공건조기(SID-2, Shinil Ind. co., Yongin, Korea)를 사용 하여 $20^{\circ} \mathrm{C}, 25^{\circ} \mathrm{C}, 30^{\circ} \mathrm{C}$ 에서 건조하였다. 히트펌프제습건조 는 히트펌프제습건조기(HPHD-1, Moojige Eng., Jeju, Korea)를 사용하여 $30^{\circ} \mathrm{C}, 40^{\circ} \mathrm{C}, 50^{\circ} \mathrm{C}$ 에서 건조하였으며, 동 결건조는 $-80^{\circ} \mathrm{C}$ 의 초저온냉동고(IU2886D, Thermo Fisher Scientific., Waltham, MA, USA)로 시료를 동결시킨 후 동결 건조기(VDF0050, Biocryos., Pyeongtaek, Korea)로 시료를 건조하였다. 새송이버섯, 이슬송이버섯, 잎새버섯의 수분 함량은 11-13\%정도로 건조하였으며, 건조시간은 버섯의 종류와 온도에 따라 다르게 나타났다. 천일건조는 9-13시 간, $40^{\circ} \mathrm{C}$ 열풍건조는 $7-8$ 시간, $50^{\circ} \mathrm{C}$ 열풍건조는 $4-5$ 시간, $60^{\circ} \mathrm{C}$ 열풍건조는 3 시간, $20^{\circ} \mathrm{C}$ 진공저온건조는 $7-10$ 시간, 2 $5^{\circ} \mathrm{C}$ 진공저온건조는 7-8시간, $30^{\circ} \mathrm{C}$ 진 공저온건조는 5-7시 간, $30^{\circ} \mathrm{C}$ 히트펌프제습건조는 8 시간, $40^{\circ} \mathrm{C}$ 히트펌프제습건 조는 6-8시간, $50^{\circ} \mathrm{C}$ 히트펌프제습건조는 4-7시간, 동결건조 는 20 시간 정도로 건조하였다.

색도 측정

색도는 버섯의 표면을 색차계(Minolta spectrophotometer, CM-3500d, Tokyo, Japan)를 이용하여 명도 $\left(\mathrm{L}^{*}\right.$-value, lightness), 적색도(a ${ }^{*}$-value, redness) 및 황색도( $\mathrm{b}^{*}$-Value, yellowness)값을 3회 반복 측정하여 평균값으로 나타내었 다.

\section{갈변도 측정}

시료 $5 \mathrm{~g}$ 에 $50 \%$ 에탄올 $50 \mathrm{~mL}$ 을 가하여 실온에서 24 시간 동안 추출한 다음 여과지(Whatman No.2)로 여과하여 UV spectrometer(UV-2700, Shimadzu, Kyoto, Japan)로 $420 \mathrm{~nm}$ 에서 흡광도 측정하였다.

경도 측정

경도측정은 texture analyzer(TA/XT 2i, Stable Micro systems Co., Surrey, UK)를 이용하였으며, 건조방법별 각 
시료를 무작위로 10 개를 선택하여 건조버섯을 상단부, 중 앙부, 하단부 3 부분으로 나누어 측정하였다. 직경 $2 \mathrm{~mm}$ needle probe으로 측정하였으며, 기기조건은 pre-test speed $2.0 \mathrm{~mm} / \mathrm{sec}$, test speed $1 \mathrm{~mm} / \mathrm{sec}$, post-test speed $5.0 \mathrm{~mm} / \mathrm{sec}$, target mode distance, distance $2.0 \mathrm{~mm}$, trigger force $5.0 \mathrm{~g}$ 으로 설정하였다.

\section{일반성분 분석}

일반성분 분석은 Association of Official Analytical Chemists(AOAC) 방법(18)에 준하여 실시하였는데, 수분은 $105^{\circ} \mathrm{C}$ 상압가열건조법, 조단백질은 Kjeldahl법으로 단백질 추출기(Tecator 1035, Sweden), 조지방은 Soxhlet 추출법 및 조회분은 회화법으로 분석하였다.

\section{베타글루칸 분석}

베타글루칸 함량은 beta-glucan kit(Megazyme, Wicklow, Ireland)를 사용하여 측정하였다. 즉, $\beta$-glucan의 함량은 total glucan과 glucan 이외의 당 함량을 구한 후, a-glucan과 glucan 이외의 당 함량 차이로 측정하였다. 즉, 시료에 $37 \%$ 염산을 첨가하여 $100^{\circ} \mathrm{C}$ 에서 2시간 동안 가수분해 시킨 후 $2 \mathrm{~N} \mathrm{KOH}$ 를 이용하여 $\mathrm{pH}$ 를 조정하였다. 가수 분해액을 $200 \mathrm{mM}$ 의 sodium acetate buffer(pH 5.0)로 희석한 후 원심 분리하고 상층액 $100 \mu \mathrm{L}$ 을 취하여 exo 1,3- $\beta$-glucanase와 $\beta$-glucosidase를 첨가한 후 glucose determination reagent (Megazyme)를 첨가하고, $510 \mathrm{~nm}$ 에서 흡광도를 측정하여 total glucan과 glucan 이외의 당 함량을 분석하였다. $a$ -glucan과 glucan 이외의 당함량은 시료에 $2 \mathrm{M} \mathrm{KOH}$ 를 넣고 20 분간 얼음이 채워진 수욕에서 반응 후 $1.2 \mathrm{M}$ sodium acetate buffer(pH 3.8)를 첨가하고 amyloglucosidase와 invertase를 넣고, 이후 새 튜브에 옮겨 glucose oxidase/ peroxidase/4-amino-anipyrine(GOPOD) reagent $3 \mathrm{~mL}$ 을 넣 어 $40^{\circ} \mathrm{C}$ 에서 20 분간 반응시킨 후 $510 \mathrm{~nm}$ 에서 흡광도를 측정한 후 다음 식으로 계산하였다.

\section{Total glucan $(\% \mathrm{w} / \mathrm{w}): \Delta \mathrm{E} \times \mathrm{F} / \mathrm{W} \times 90$}

a-glucan $(\% \mathrm{w} / \mathrm{w}): \Delta \mathrm{E} \times \mathrm{F} / \mathrm{W} \times 90$ (final volume $100 \mathrm{~mL}$ )

$\beta$-glucan : Total glucan-(a-glucan)

$\Delta \mathrm{E}$ : reaction absorbance-blank absorbance

F : 100/GOPOD reagent absorbance for $100 \mu \mathrm{g}$ of D-glucose standard

W : weight of sample

\section{통계처리}

SAS 프로그램(SAS 9.1, SAS Institute Inc., Cary, NC, USA)을 이용하여 Duncan's Multiple Range Test(DMRT)를 실시하였으며 유의차를 $5 \%$ 수준에서 검증하였다.

\section{결과 및 고찰}

색 도

버섯의 색택은 버섯 건조품의 품질을 판정하는데 중요한 구매 요인으로 작용한다. 건조방법에 따른 새송이버섯의 색도를 Table 1에 나타내었으며, 새송이버섯의 경우 자실체 의 대 부분은 색상이 밝아 건조하면 다른 버섯에 비해 색상 의 변화가 크며, 건조 후 육안으로 관찰한 결과 동결건조를 제외한 다른 건조방법에서는 색상의 변화가 있었다.

새송이버섯은 $30^{\circ} \mathrm{C}, 50^{\circ} \mathrm{C}$ 히트펌프제습건조와 $30^{\circ} \mathrm{C}$ 저온 진공건조를 제외하고는 대조구와 비슷한 색도 $\mathrm{L}^{*}$ (lightness) 값을 나타내었으며, a (redness) 값은 천일건조와 $40^{\circ} \mathrm{C}, 50^{\circ} \mathrm{C}$ 히트펌프제습건조에서 적색도가 높은 경향을 보였다. $\mathrm{b}^{*}$ (yellowness) 값은 대조구와 동결건조가 가장 낮은 값으로 황색도의 변화가 가장 적었다. 새송이버섯 건조시 동결건 조가 가장 $\mathrm{L}^{*}$ 값, $\mathrm{a}^{*}$ 값, $\mathrm{b}^{*}$ 값이 대조구와 비슷한 경향을 보였다. 저온진공건조의 경우 온도가 높아질수록 $\mathrm{L}^{*}$ 값, $\mathrm{a}^{*}$ 값은 감소하고 $\mathrm{b}^{*}$ 값은 증가하여 명도와 적색도는 감소하 고 황색도는 증가하는 경향이었다. 양송이버섯에서도 진공 건조 온도가 높아질수록 $\mathrm{L}^{*}$ 값은 감소하였다(19).

Table 1. Changes of color value in dried Pleurotus eryngii by different drying methods

\begin{tabular}{|c|c|c|c|c|}
\hline \multirow{2}{*}{\multicolumn{2}{|c|}{ Drying methods }} & \multicolumn{3}{|c|}{ Hunter value ${ }^{1)}$} \\
\hline & & $L^{*}$ & $a^{*}$ & $b^{*}$ \\
\hline Control & & $91.91 \pm 0.88^{2 / 23)}$ & $-0.44 \pm 0.13^{\mathrm{ab}}$ & $8.90 \pm 0.21^{\mathrm{e}}$ \\
\hline Sun-drying & & $90.06 \pm 0.86^{\mathrm{a}}$ & $0.08 \pm 0.13^{\mathrm{a}}$ & $13.26 \pm 0.74^{\mathrm{cd}}$ \\
\hline \multirow{3}{*}{ Hot-air drying } & 40 & $91.52 \pm 0.09^{\mathrm{a}}$ & $-1.12 \pm 0.11^{\mathrm{c}}$ & $14.27 \pm 0.68^{\mathrm{bc}}$ \\
\hline & 50 & $92.22 \pm 0.94^{\mathrm{a}}$ & $-1.85 \pm 0.11^{\mathrm{d}}$ & $14.18 \pm 0.11^{\text {bc }}$ \\
\hline & 60 & $91.77 \pm 0.65^{\mathrm{a}}$ & $-1.52 \pm 0.28^{\mathrm{cd}}$ & $12.88 \pm 0.94^{\mathrm{cd}}$ \\
\hline \multirow{3}{*}{$\begin{array}{l}\text { Low temperature } \\
\text { vacuum drying }\end{array}$} & 20 & $91.63 \pm 0.45^{\mathrm{a}}$ & $-0.94 \pm 0.10^{\text {bc }}$ & $12.86 \pm 0.19^{\text {cd }}$ \\
\hline & 25 & $91.17 \pm 0.63^{\mathrm{a}}$ & $-0.99 \pm 0.14^{\mathrm{bc}}$ & $13.93 \pm 0.13^{\mathrm{bc}}$ \\
\hline & 30 & $86.25 \pm 0.21^{b}$ & $-1.14 \pm 0.11^{\mathrm{c}}$ & $17.55 \pm 1.50^{\mathrm{a}}$ \\
\hline \multirow{3}{*}{$\begin{array}{l}\text { Heat pump } \\
\text { dehumidifying drying }\end{array}$} & 30 & $85.55 \pm 0.63^{b}$ & $-1.34 \pm 0.14^{\text {cd }}$ & $16.88 \pm 0.20^{\mathrm{ab}}$ \\
\hline & 40 & $90.44 \pm 0.81^{\mathrm{a}}$ & $-0.15 \pm 0.27^{\mathrm{a}}$ & $14.10 \pm 0.54^{\mathrm{bc}}$ \\
\hline & 50 & $83.98 \pm 0.12^{b}$ & $0.17 \pm 0.53^{\mathrm{a}}$ & $19.29 \pm 0.82^{\mathrm{a}}$ \\
\hline Freeze drying & & $92.00 \pm 0.33^{\mathrm{a}}$ & $-0.89 \pm 0.17^{\mathrm{bc}}$ & $10.32 \pm 1.00^{\mathrm{de}}$ \\
\hline
\end{tabular}

${ }^{1)} L^{*}$, lightness; $a^{*}$, redness; $b^{*}$, yellowness.

${ }^{2)}$ All values represent mean \pm SD.

${ }^{33}$ Means with different letters $\left.{ }^{2-9}\right)$ with in a column are significantly different $(\mathrm{p}<0.05)$.

건조방법에 따른 이슬송이버섯의 색도를 Table 2에 나타 내었다. 이슬송이버섯은 $25^{\circ} \mathrm{C}, 30^{\circ} \mathrm{C}$ 저온진공건조에서 대 조구와 비슷한 $\mathrm{L}^{*}$ 값을 보였으며, $\mathrm{a}^{*}$ 값은 대조구와 천일건 조, $40^{\circ} \mathrm{C}, 50^{\circ} \mathrm{C}$ 열풍건조, $20^{\circ} \mathrm{C}$ 저온진공건조, $50^{\circ} \mathrm{C}$ 히트펌프 제습건조, 동결건조에서 비슷한 경향을 보였다. $b^{*}$ 값은 대조구에 비해 대체적으로 황색도가 높았다. 전체적으로 
Table 2. Changes of color value in dried Lentinula edodes GNAO1 by different drying methods

\begin{tabular}{|c|c|c|c|c|}
\hline \multirow{2}{*}{\multicolumn{2}{|c|}{ Drying methods }} & \multicolumn{3}{|c|}{ Hunter value ${ }^{1)}$} \\
\hline & & $\mathrm{L}^{*}$ & $a^{*}$ & $b^{*}$ \\
\hline Control & & $91.05 \pm 1.09^{2 / 23)}$ & $1.00 \pm 0.24^{\mathrm{abc}}$ & $8.07 \pm 0.45^{\mathrm{e}}$ \\
\hline Sun-drying & & $87.51 \pm 0.33^{\mathrm{bc}}$ & $0.84 \pm 0.07^{\mathrm{abc}}$ & $11.23 \pm 0.50^{\text {bcd }}$ \\
\hline \multirow{3}{*}{ Hot-air drying } & 40 & $88.19 \pm 0.62^{\mathrm{abc}}$ & $0.82 \pm 0.06^{\mathrm{abc}}$ & $11.52 \pm 0.54^{\text {abcd }}$ \\
\hline & 50 & $88.34 \pm 1.06^{\mathrm{abc}}$ & $0.81 \pm 0.04^{\mathrm{abc}}$ & $10.99 \pm 0.48^{\text {cd }}$ \\
\hline & 60 & $88.73 \pm 0.52^{\mathrm{abc}}$ & $0.72 \pm 0.05^{\mathrm{bc}}$ & $10.75 \pm 0.30^{\mathrm{d}}$ \\
\hline \multirow{3}{*}{$\begin{array}{l}\text { Low temperature } \\
\text { vacuum drying }\end{array}$} & 20 & $86.76 \pm 1.20^{c}$ & $0.91 \pm 0.18^{\mathrm{abc}}$ & $12.49 \pm 0.05^{\mathrm{a}}$ \\
\hline & 25 & $90.25 \pm 1.00^{\mathrm{ab}}$ & $0.60 \pm 0.13^{c}$ & $10.39 \pm 0.45^{\mathrm{d}}$ \\
\hline & 30 & $90.34 \pm 0.07^{\mathrm{ab}}$ & $0.58 \pm 0.04^{\mathrm{c}}$ & $10.59 \pm 0.71^{\mathrm{d}}$ \\
\hline \multirow{3}{*}{$\begin{array}{c}\text { Heat pump } \\
\text { dehumidifying drying }\end{array}$} & 30 & $86.18 \pm 0.16^{\mathrm{c}}$ & $1.35 \pm 0.14^{\mathrm{a}}$ & $12.08 \pm 0.24^{\mathrm{abc}}$ \\
\hline & 40 & $86.22 \pm 1.21^{\mathrm{c}}$ & $1.31 \pm 0.06^{\mathrm{ab}}$ & $11.37 \pm 0.24^{\mathrm{abcd}}$ \\
\hline & 50 & $89.27 \pm 0.70^{\mathrm{abc}}$ & $0.79 \pm 0.07^{\mathrm{abc}}$ & $10.86 \pm 0.37^{\mathrm{d}}$ \\
\hline Freeze drying & & $87.49 \pm 0.35^{\mathrm{bc}}$ & $1.05 \pm 0.30^{\mathrm{abc}}$ & $12.36 \pm 1.10^{\mathrm{ab}}$ \\
\hline
\end{tabular}

${ }^{1)}{ }^{*}$, lightness; $a^{*}$, redness; $b^{*}$, yellowness.

${ }^{2)}$ All values represent mean $\pm \mathrm{SD}$.

${ }^{3}$ Means with different letters $(\mathrm{a} e)$ with in a column are significantly different $(\mathrm{p}<0.05)$.

저온진공건조가 다른 건조에 비해 대조구와 비슷한 경향을 보였다. 양송이버섯, 목이버섯, 표고버섯을 원형 그대로 열 풍건조하였을 때 온도가 높아질수록 $\mathrm{L}^{\star}$ 값은 감소하고 $\mathrm{a}^{*}$ 와 $\mathrm{b}^{*}$ 값은 증가하지만 $(19,20)$ 이슬송이버섯은 건조온도가 높 아질수록 $\mathrm{L}^{*}$ 값은 증가하였다. 복령에서는 열풍건조에 따른 $\mathrm{L}^{*}$ 값의 변화가 본 실험과 유사하였다(21). 이러한 원인은 건조 전 슬라이스 처리의 유무에 따른 차이와 온도가 높아 질수록 건조시간이 짧아짐에 따라 대기 중의 수분과 접촉하 는 시간이 줄어들어 $\mathrm{L}^{*}$ 값이 증가되는 것으로 생각된다.

건조방법에 따른 잎새버섯의 색도를 Table 3에 나타내었 다. 잎새버섯은 건조하면 대조구에 비해 명도가 낮아지는 경향을 보였으며, $\mathrm{a}^{*}$ 값은 건조방법과 건조온도에 따른 유 의적인 차이는 없었으며, $\mathrm{b}^{*}$ 값은 천일건조에서 대조구와 비슷한 경향을 보였으며, 다른 버섯에 비해 생버섯 자체에 서 황색도가 높았으며, 건조하게 되면 낮아지는 경향을 보 였다. 전체적으로 다른 버섯에 비해 건조방법과 건조온도 에 따른 유의적인 차이는 없었다.

\section{갈변도}

갈변현상은 polyphenoloxidase(PPO)와 같은 효소에 의한 페놀성 물질의 산화에 의해서 발생되며 건조시 온도에 의한 maillard 반응 또한 갈변의 주원인이라고 할 수 있다. 건조방 법에 따른 버섯의 갈변정도를 가용성 추출물을 이용하여 $420 \mathrm{~nm}$ 에서 흡광도를 측정한 결과를 Table 4에 나타내었다. 새송이버섯은 대조구에 비해 $50^{\circ} \mathrm{C}$ 열풍건조에서 갈변도가 가장 높은 경향을 보였으며, 동결건조에서 갈변도가 가장 낮았다. 이슬송이는 $60^{\circ} \mathrm{C}$ 열 풍건조, $20^{\circ} \mathrm{C}$ 저온진공건조, $50^{\circ} \mathrm{C}$ 히트펌프제습건조에서 갈변도가 높은 경향을 보였으 며, $40^{\circ} \mathrm{C}$ 열풍건조에서는 갈변도가 낮았다. 잎새버섯은 천 일건조, $40^{\circ} \mathrm{C}, 50^{\circ} \mathrm{C}$ 히트펌프제습건조에서 갈변도가 높은 경향을 보였으며, $60^{\circ} \mathrm{C}$ 열풍건조에서는 갈변도가 낮았다. 새송이버섯, 이슬송이버섯, 잎새버섯 모두 저온진공건조는 온도가 높아질수록 갈변도는 감소하였으며 히트펌프제습 건조는 온도가 높아질수록 증가하는 경향을 나타내었다. 이슬송이버섯은 열풍건조의 온도가 높을수록 갈변도는 증

Table 3. Changes of color value in dried Grifola frondosa by different drying methods

\begin{tabular}{|c|c|c|c|c|}
\hline \multirow{2}{*}{\multicolumn{2}{|c|}{ Drying methods }} & \multicolumn{3}{|c|}{ Hunter value $^{1)}$} \\
\hline & & $\mathrm{L}^{*}$ & $a^{*}$ & $b^{*}$ \\
\hline Control & & $62.23 \pm 1.35^{2) 33)}$ & $2.67 \pm 1.05^{\mathrm{a}}$ & $15.63 \pm 0.98^{\mathrm{a}}$ \\
\hline Sun-drying & & $49.50 \pm 0.96^{\mathrm{ab}}$ & $3.29 \pm 0.54^{a}$ & $15.77 \pm 0.66^{\mathrm{a}}$ \\
\hline \multirow{3}{*}{ Hot-air drying } & 40 & $37.37 \pm 3.95^{b}$ & $2.35 \pm 0.45^{\mathrm{a}}$ & $10.28 \pm 0.02^{b c}$ \\
\hline & 50 & $50.43 \pm 2.25^{\mathrm{ab}}$ & $2.71 \pm 0.65^{\mathrm{a}}$ & $13.57 \pm 0.70^{\mathrm{abc}}$ \\
\hline & 60 & $50.00 \pm 2.53^{\mathrm{ab}}$ & $2.69 \pm 0.51^{\mathrm{a}}$ & $13.6 \pm 0.62^{\mathrm{abc}}$ \\
\hline \multirow{3}{*}{$\begin{array}{l}\text { Low temperature } \\
\text { vacuum drying }\end{array}$} & 20 & $41.76 \pm 5.03^{b}$ & $2.56 \pm 0.38^{a}$ & $13.12 \pm 1.28^{\mathrm{abc}}$ \\
\hline & 25 & $44.43 \pm 3.06^{b}$ & $3.03 \pm 0.45^{\mathrm{a}}$ & $13.20 \pm 0.99^{\mathrm{abc}}$ \\
\hline & 30 & $51.22 \pm 3.16^{\mathrm{ab}}$ & $2.51 \pm 0.92^{\mathrm{a}}$ & $14.76 \pm 0.56^{\mathrm{ab}}$ \\
\hline \multirow{3}{*}{$\begin{array}{l}\text { Heat pump } \\
\text { dehumidifying drying }\end{array}$} & 30 & $43.40 \pm 4.87^{b}$ & $2.42 \pm 0.35^{\mathrm{a}}$ & $11.09 \pm 0.23^{\mathrm{abc}}$ \\
\hline & 40 & $44.57 \pm 4.16^{b}$ & $2.08 \pm 0.22^{\mathrm{a}}$ & $9.06 \pm 0.47^{\mathfrak{c}}$ \\
\hline & 50 & $41.03 \pm 1.72^{b}$ & $3.08 \pm 0.20^{\mathrm{a}}$ & $13.26 \pm 0.11^{\mathrm{abc}}$ \\
\hline Freeze drying & & $46.13 \pm 0.98^{b}$ & $2.20 \pm 0.06^{\mathrm{a}}$ & $10.31 \pm 0.29^{\mathrm{bc}}$ \\
\hline
\end{tabular}

${ }^{11} L^{*}$, lightness; $a{ }^{*}$, redness; $b$, yellowness.

${ }^{2)}$ All values represent mean $\pm \mathrm{SD}$.

${ }^{33}$ Means with different letters $\left({ }^{-0}\right)$ with in a column are significantly different $(p<0.05)$.

Table 4. Changes of browning degree (OD $420 \mathrm{~nm}$ ) in dried mushroom by different drying methods

\begin{tabular}{|c|c|c|c|c|}
\hline \multicolumn{2}{|c|}{ Drying methods } & Pleurotus eryngii & $\begin{array}{c}\text { Lentinula edodes } \\
\text { GNA01 }\end{array}$ & Grifola frondosa \\
\hline \multicolumn{2}{|l|}{ Control } & $0.22 \pm 0.05^{1)(2)}$ & $0.24 \pm 0.02^{b}$ & $0.37 \pm 0.02^{\mathrm{d}}$ \\
\hline \multicolumn{2}{|l|}{ Sun-drying } & $0.43 \pm 0.03^{\mathrm{ab}}$ & $0.25 \pm 0.05^{b}$ & $1.13 \pm 0.05^{\mathrm{a}}$ \\
\hline \multirow{3}{*}{ Hot-air drying } & 40 & $0.41 \pm 0.03^{\mathrm{ab}}$ & $0.22 \pm 0.08^{b}$ & $0.94 \pm 0.08^{b}$ \\
\hline & 50 & $0.48 \pm 0.02^{\mathrm{a}}$ & $0.28 \pm 0.05^{\mathrm{b}}$ & $0.78 \pm 0.05^{\mathrm{c}}$ \\
\hline & 60 & $0.31 \pm 0.06^{\text {cde }}$ & $0.38 \pm 0.02^{\mathrm{a}}$ & $0.75 \pm 0.02^{c}$ \\
\hline \multirow{3}{*}{$\begin{array}{l}\text { Low temperature } \\
\text { vacuum drying }\end{array}$} & 20 & $0.28 \pm 0.01^{\text {def }}$ & $0.39 \pm 0.03^{\mathrm{a}}$ & $0.97 \pm 0.03^{b}$ \\
\hline & 25 & $0.25 \pm 0.06^{\mathrm{ef}}$ & $0.32 \pm 0.09^{\mathrm{ab}}$ & $0.86 \pm 0.02^{\mathrm{bc}}$ \\
\hline & 30 & $0.21 \pm 0.05^{\mathrm{f}}$ & $0.32 \pm 0.02^{\mathrm{ab}}$ & $0.85 \pm 0.09^{\mathrm{bc}}$ \\
\hline \multirow{3}{*}{$\begin{array}{l}\text { Heat pump } \\
\text { dehumidifying } \\
\text { drying }\end{array}$} & 30 & $0.28 \pm 0.02^{\text {def }}$ & $0.31 \pm 0.01^{\mathrm{ab}}$ & $0.76 \pm 0.03^{c}$ \\
\hline & 40 & $0.28 \pm 0.07^{\mathrm{def}}$ & $0.31 \pm 0.03^{\mathrm{ab}}$ & $1.16 \pm 0.01^{\mathrm{a}}$ \\
\hline & 50 & $0.35 \pm 0.03^{\mathrm{bcd}}$ & $0.40 \pm 0.06^{\mathrm{a}}$ & $1.18 \pm 0.06^{\mathrm{a}}$ \\
\hline \multicolumn{2}{|c|}{ Freeze drying } & $0.13 \pm 0.02^{f}$ & $0.32 \pm 0.08^{\mathrm{ab}}$ & $0.87 \pm 0.08^{b c}$ \\
\hline
\end{tabular}

${ }^{1)}$ All values represent mean \pm SD.

${ }^{2}$ Means with different letters $(\stackrel{0-f}{)}$ ) with in a column are significantly different $(\mathrm{p}<0.05)$. 
가하는 경향을 보였으며, 표고버섯에서도 열풍건조의 온도 가 높고 건조실내의 상대습도가 높을수록 갈변도는 증가하 는 경향이었다.(22)

\section{경 도}

건조방법에 따른 버섯의 경도를 Table 5 에 나타내었다. 새송이버섯은 $40^{\circ} \mathrm{C}, 50^{\circ} \mathrm{C}$ 히트펌프제습건조에서 경도가 높 은 경향을 보였으며, 열풍건조, 저온진공건조, 히트펌프제 습건조에서 온도가 높아질수록 경도 값은 증가하였다. 양 송이버섯도 열풍건조에서 이와 유사한 결과를 보였는데 (19) 이러한 원인은 열풍건조는 열이 표면 외부에서 내부로 전도되는데, 버섯내부의 수분 이동속도는 외부보다 낮아 표면의 조직은 치밀해지고, 온도가 높아짐에 따라 경도가 증가한다(23). 이슬송이버섯은 천일건조에서 경도가 가장 높은 경향을 보였으며, 열풍건조와 히트펌프제습건조에서 온도가 높아질수록 경도가 증가하는 경향을 보였다. 잎새 버섯 또한 천일건조에서 경도가 가장 높은 경향을 보였다. 동결건조에서 다른 건조방법에 비해 경도가 낮은 값을 보였 다. $\mathrm{Ha}$ 등(2)의 건조방법에 따른 양송이버섯의 건조에 관한 연구에서 동결건조의 경우 다른 건조에 비해 경도변화가 적었으며, 이는 건조되었다 하더라도 조직내부가 다공성으 로 이루어졌기 때문이라 사료된다는 보고와 일치하였다.

Table 5. Changes of hardness $\left(\mathrm{g} / \mathrm{cm}^{2}\right)$ in dried mushroom by different drying methods

\begin{tabular}{|c|c|c|c|c|}
\hline \multicolumn{2}{|c|}{ Drying methods } & Pleurotus eryngii & $\begin{array}{l}\text { Lentinula edodes } \\
\text { GNAO1 }\end{array}$ & Grifola frondosa \\
\hline \multicolumn{2}{|l|}{ Control } & $109.07 \pm 28.00^{1 \mathrm{bb} 2)}$ & $132.74 \pm 33.92^{\mathrm{e}}$ & $125.97 \pm 37.31^{\mathrm{e}}$ \\
\hline \multicolumn{2}{|l|}{ Sun-drying } & $281.89 \pm 57.41^{\mathrm{ab}}$ & $372.45 \pm 64.73^{\mathrm{a}}$ & $542.85 \pm 83.51^{\mathrm{a}}$ \\
\hline \multirow{3}{*}{ Hot-air drying } & 40 & $175.87 \pm 55.14^{\mathrm{ab}}$ & $189.44 \pm 49.57^{\mathrm{d}}$ & $336.72 \pm 64.53^{\mathrm{bcd}}$ \\
\hline & 50 & $191.86 \pm 45.67^{\mathrm{ab}}$ & $191.74 \pm 32.13^{\mathrm{d}}$ & $300.72 \pm 63.37^{\text {bcd }}$ \\
\hline & 60 & $209.67 \pm 48.79^{\mathrm{ab}}$ & $209.25 \pm 39.14^{d}$ & $226.11 \pm 48.00^{\mathrm{de}}$ \\
\hline \multirow{3}{*}{$\begin{array}{l}\text { Low temperature } \\
\text { vacuum drying }\end{array}$} & 20 & $203.05 \pm 81.84^{\mathrm{ab}}$ & $309.33 \pm 100.87^{b}$ & $392.62 \pm 66.17^{\mathrm{bc}}$ \\
\hline & 25 & $208.51 \pm 89.17^{\mathrm{ab}}$ & $317.22 \pm 88.57^{b}$ & $439.48 \pm 67.05^{b}$ \\
\hline & 30 & $229.73 \pm 80.33^{\mathrm{ab}}$ & $257.34 \pm 95.97^{\mathrm{c}}$ & $270.84 \pm 53.46^{\text {cde }}$ \\
\hline \multirow{3}{*}{$\begin{array}{l}\text { Heat pump } \\
\text { dehumidifying } \\
\text { drying }\end{array}$} & 30 & $187.95 \pm 76.83^{\mathrm{ab}}$ & $210.76 \pm 84.72^{\text {cd }}$ & $362.70 \pm 80.25^{\text {bcd }}$ \\
\hline & 40 & $366.57 \pm 93.70^{a}$ & $247.74 \pm 85.87^{\mathrm{c}}$ & $338.67 \pm 79.95^{\text {bd }}$ \\
\hline & 50 & $414.31 \pm 103.96^{\mathrm{a}}$ & $308.08 \pm 106.05^{\mathrm{b}}$ & $329.67 \pm 89.64^{\mathrm{bcd}}$ \\
\hline \multicolumn{2}{|c|}{ Freeze Drying } & $237.44 \pm 49.86^{\mathrm{ab}}$ & $259.95 \pm 74.05^{\mathrm{c}}$ & $136.4 \pm 40.94^{e}$ \\
\hline
\end{tabular}

${ }^{1)}$ All values represent mean $\pm \mathrm{SD}$.

${ }^{2}$ Means with different letters $\left({ }^{\mathrm{t}} \mathrm{C}\right)$ with in a column are significantly different $(\mathrm{p}<0.05)$.

\section{일반성분}

건조방법에 따른 새송이버섯의 일반성분 함량은 Table 6에 나타내었으며, 새송이버섯, 이슬송이버섯, 잎새버섯의 수분 함량은 11-13\%정도로 건조하였다. 새송이버섯의 단 백질 함량은 동결건조가 $18.00 \%$ 로 가장 낮은 경향을 보였
으며, $40^{\circ} \mathrm{C}$ 열풍건조에서 $23.36 \%$ 으로 가장 높은 경향을 보였다. 지방 함량은 $40^{\circ} \mathrm{C}$ 히트펌프제습건조에서 $0.75 \%$ 로 가장 낮은 경향을 보였으며, $30^{\circ} \mathrm{C}$ 히트펌프제습건조에서 $1.30 \%$ 로 가장 높은 경향을 보였다. 회분 함량은 천일건조가 $4.96 \%$ 로 가장 낮은 함량을 나타내었으며, $60^{\circ} \mathrm{C}$ 열풍건조에 서 $6.09 \%$ 로 가장 높은 함량을 나타내었지만, $5 \%$ 의 수준에 서 유의적 차이는 없는 것으로 나타났다. 이슬송이버섯의 일반성분 함량은 Table 7에 나타내었다. 단백질 함량은 2 $5{ }^{\circ} \mathrm{C}$ 저온진공건조에서 $17.92 \%$ 로 가장 낮은 경향을 보였으 며, $40^{\circ} \mathrm{C}, 50^{\circ} \mathrm{C}$ 히트펌프제습건조에서 $20.40-20.60$ 으로 가 장 높은 경향을 보였다. 지방 함량은 천일건조에서 $0.68 \%$ 로 가장 낮은 경향을 보였으며, $20^{\circ} \mathrm{C}$ 저온진공건조에서 $1.86 \%$ 로 가장 높은 경향을 보였다. 회분 함량은 $25^{\circ} \mathrm{C}$ 저온진공건 조, $30^{\circ} \mathrm{C}$ 히트펌프제습건조에서 5.36-5.41\%로 가장 낮은 경향을 보였다. 천일건조, $40^{\circ} \mathrm{C}$ 열풍건조에서 $7.61-7.77 \%$ 로 가장 높은 경향을 보였다. 잎새버섯의 일반성분 함량은 Table 8 에 나타내었다. 단백질 함량은 $50^{\circ} \mathrm{C}$ 열 풍건조, $30^{\circ} \mathrm{C}$ 저온진공건조, $30^{\circ} \mathrm{C}$ 히트펌프제습건조에서 $26.63-26.85 \%$ 으로 낮은 경향을 보였으며, $50^{\circ} \mathrm{C}$ 히트펌프제습건조, 동결 건조에서 32.81-33.07\%으로 높은 경향을 보였다. 지방 함량 은 $50^{\circ} \mathrm{C}$ 히트펌프제습건조에서 $2.44 \%$ 로 가장 높은 경향을 보였으며, 다른 건조방법은 $5 \%$ 의 수준에서 유의적 차이는 없는 것으로 나타났다. 회분 함량은 $50^{\circ} \mathrm{C}$ 열풍건조, $40,50^{\circ} \mathrm{C}$ 히트펌프제습건조, 동결건조에서 $7.00-7.90 \%$ 로 가장 낮은 경향을 보였으며, $25^{\circ} \mathrm{C}$ 저온진공건조에서 $8.83 \%$ 로 가장 높은 함량을 나타내었다. 전체적으로 새송이버섯, 이슬송 이버섯, 잎새버섯의 단백질 함량은 $18.00-23.36 \%$, 17.92-20.60\%, 26.63-33.07\%로 잎새버섯 > 새송이버섯 > 이슬송이버섯 순으로 나타났으며, 지방 함량은 0.75-1.30\%, $0.68-1.86 \%, 1.88-2.44 \%$ 로 잎새버섯 > 이슬송이버섯 > 잎새 버섯 순으로 나타났으며, 회분 함량은 $4.96-6.09 \%, 5.36$ $7.77 \%, 7.00-8.83 \%$ 로 잎새버섯 > 이슬송이버섯 > 새송이버 섯 순으로 나타났다. 버섯의 생버섯과 건버섯의 함량은 농 촌진흥청에서 보고한 식품성분표의 결과와 비슷하였다. Jin 등(24)은 표고버섯과 양송이버섯을 열풍건조와 동결건 조한 결과 건조방법에 따른 유의적인 차이가 없는 것으로 보고하였다.

\section{베타글루칸}

베타글루칸은 $\beta(1 \rightarrow 3), \beta(1 \rightarrow 4), \beta(1 \rightarrow 6)$ 결합의 복잡한 구조를 이루고 있으며, 이는 대식세포를 활성화 시켜 암세 포가 있는 체내로 들어가 여러 가지 사이토카인의 분비를 촉진시킴으로써 면역세포인 $\mathrm{T}$ 세포와 $\mathrm{B}$ 세포의 면역기능을 활성화시킨다. 이 외에도 세균, 바이러스, 곰팡이, 기생충에 저항성을 가지며, 비특이적 면역반응을 일으켜 정상세포의 면역기능을 활성화시키며, 혈당강하 및 혈중 콜레스테롤 감소 효과가 있다고 보고되었다(14,25). 건조방법에 따른 
Table 6. Changes of general components (\%) in dried pleurotus eryngii by different drying methods

\begin{tabular}{|c|c|c|c|c|c|}
\hline \multirow{2}{*}{ Drying methods } & & \multicolumn{4}{|c|}{ Pleurotus eryngii } \\
\hline & & Moisture & Protein & Fat & Ash \\
\hline Control & & $89.26 \pm 0.20^{1 / \mathrm{a} 2)}$ & $2.8 \pm 0.11^{\mathrm{g}}$ & $0.05 \pm 0.00^{g}$ & $1.00 \pm 0.05^{\mathrm{b}}$ \\
\hline Sun-drying & & $11.33 \pm 0.08^{\mathrm{fg}}$ & $19.01 \pm 0.47^{\mathrm{f}}$ & $1.00 \pm 0.08^{\text {cde }}$ & $4.96 \pm 0.17^{\mathrm{a}}$ \\
\hline \multirow{3}{*}{ Hot-air drying } & 40 & $12.51 \pm 0.29^{\text {bcd }}$ & $23.36 \pm 0.21^{\mathrm{a}}$ & $1.10 \pm 0.05^{\mathrm{bcd}}$ & $5.68 \pm 0.03^{\mathrm{a}}$ \\
\hline & 50 & $12.04 \pm 0.54^{\mathrm{de}}$ & $20.01 \pm .021^{\mathrm{de}}$ & $0.90 \pm 0.10^{\text {ef }}$ & $5.26 \pm 0.06^{\mathrm{a}}$ \\
\hline & 60 & $12.79 \pm 0.35^{b}$ & $21.38 \pm 0.07^{\mathrm{bcd}}$ & $1.10 \pm 0.03^{\text {bcd }}$ & $6.09 \pm 0.30^{\mathrm{a}}$ \\
\hline \multirow{3}{*}{ Low temperature vacuum drying } & 20 & $12.78 \pm 0.46^{b}$ & $20.49 \pm 0.57^{\text {dde }}$ & $1.15 \pm 0.03^{\mathrm{abc}}$ & $4.98 \pm 0.30^{\mathrm{a}}$ \\
\hline & 25 & $12.22 \pm 0.06^{\mathrm{cde}}$ & $22.21 \pm 0.09^{\mathrm{abc}}$ & $1.05 \pm 0.11^{\text {cde }}$ & $5.49 \pm 0.08^{\mathrm{a}}$ \\
\hline & 30 & $11.88 \pm 0.22^{\mathrm{e}}$ & $20.91 \pm 0.38^{\mathrm{bcd}}$ & $0.95 \pm 0.05^{\mathrm{de}}$ & $5.40 \pm 0.13^{\mathrm{a}}$ \\
\hline \multirow{3}{*}{ Heat pump dehumidifying drying } & 30 & $12.62 \pm 0.34^{\mathrm{bc}}$ & $21.51 \pm 0.51^{\text {abcd }}$ & $1.30 \pm 0.05^{\mathrm{a}}$ & $5.38 \pm 0.15^{\mathrm{a}}$ \\
\hline & 40 & $11.76 \pm 0.49^{\mathrm{ef}}$ & $22.52 \pm 0.89^{\mathrm{ab}}$ & $0.75 \pm 0.03^{\mathrm{f}}$ & $5.50 \pm 0.15^{\mathrm{a}}$ \\
\hline & 50 & $11.04 \pm 0.06^{\mathrm{g}}$ & $22.16 \pm 0.27^{\mathrm{abc}}$ & $1.00 \pm 0.05^{\mathrm{cde}}$ & $5.69 \pm 0.02^{\mathrm{a}}$ \\
\hline Freeze drying & & $11.03 \pm 0.30^{g}$ & $18.00 \pm 0.24^{\mathrm{f}}$ & $1.25 \pm 0.06^{\mathrm{ab}}$ & $5.08 \pm 0.17^{\mathrm{a}}$ \\
\hline
\end{tabular}

${ }^{1)}$ All values represent mean \pm SD.

${ }^{2)}$ Means with different letters $\left({ }^{-g}\right)$ with in a column are significantly different $(\mathrm{p}<0.05)$.

Table 7. Changes of general components (\%) in dried Lentinula edodes GNAO1 by different drying methods

\begin{tabular}{|c|c|c|c|c|c|}
\hline \multirow{2}{*}{ Drying methods } & & \multicolumn{4}{|c|}{ Lentinula edodes GNAO1 } \\
\hline & & Moisture & Protein & Fat & Ash \\
\hline Control & & $80.75 \pm 0.09^{\left.1 / \mathrm{a}_{2}\right)}$ & $4.27 \pm 0.06^{\mathrm{f}}$ & $0.27 \pm 0.03^{f}$ & $1.31 \pm 0.03^{\mathrm{g}}$ \\
\hline Sun-drying & & $11.14 \pm 0.23^{c}$ & $18.45 \pm 0.02^{\mathrm{d}}$ & $0.68 \pm 0.15^{\mathrm{e}}$ & $7.77 \pm 0.15^{\mathrm{a}}$ \\
\hline \multirow{3}{*}{ Hot-air drying } & 40 & $11.91 \pm 0.06^{\mathrm{bc}}$ & $18.56 \pm 0.10^{\mathrm{d}}$ & $1.62 \pm 0.10^{\mathrm{abc}}$ & $7.61 \pm 0.23^{\mathrm{a}}$ \\
\hline & 50 & $11.69 \pm 0.06^{\mathrm{bc}}$ & $18.60 \pm 0.13^{\mathrm{d}}$ & $0.81 \pm 0.16^{\mathrm{e}}$ & $5.68 \pm 0.15^{\mathrm{d} e}$ \\
\hline & 60 & $12.85 \pm 0.42^{\mathrm{b}}$ & $20.15 \pm 0.31^{\mathrm{ab}}$ & $1.31 \pm 0.06^{\mathrm{d}}$ & $5.69 \pm 0.066^{\mathrm{de}}$ \\
\hline \multirow{3}{*}{ Low temperature vacuum drying } & 20 & $12.28 \pm 0.06^{\mathrm{bc}}$ & $18.76 \pm 0.08^{\mathrm{d}}$ & $1.86 \pm 0.19^{\mathrm{a}}$ & $7.32 \pm 0.19^{\mathrm{b}}$ \\
\hline & 25 & $12.88 \pm 0.31^{\mathrm{b}}$ & $17.92 \pm 0.01^{\mathrm{e}}$ & $1.55 \pm 0.10^{\mathrm{bcd}}$ & $5.36 \pm 0.16^{\mathrm{f}}$ \\
\hline & 30 & $12.00 \pm 0.15^{\mathrm{bc}}$ & $19.86 \pm 0.20^{b}$ & $1.52 \pm 0.29^{\mathrm{bcd}}$ & $5.49 \pm 0.09^{\mathrm{ef}}$ \\
\hline \multirow{3}{*}{ Heat pump dehumidifying drying } & 30 & $11.50 \pm 0.22^{\mathrm{c}}$ & $19.31 \pm 0.16^{\mathrm{c}}$ & $1.73 \pm 0.06^{\mathrm{ab}}$ & $5.41 \pm 0.10^{f}$ \\
\hline & 40 & $11.80 \pm 0.76^{\mathrm{bc}}$ & $20.40 \pm 0.68^{\mathrm{a}}$ & $1.40 \pm 0.15^{\mathrm{cd}}$ & $5.99 \pm 0.19^{c}$ \\
\hline & 50 & $11.00 \pm 0.24^{\mathrm{c}}$ & $20.60 \pm 0.54^{\mathrm{a}}$ & $1.27 \pm 0.26^{\mathrm{d}}$ & $5.96 \pm 0.06^{\mathrm{c}}$ \\
\hline Freeze drying & & $12.11 \pm 0.84^{\mathrm{bc}}$ & $18.78 \pm 0.22^{\mathrm{d}}$ & $1.76 \pm 0.18^{\mathrm{ab}}$ & $5.83 \pm 0.11^{\mathrm{cc}}$ \\
\hline
\end{tabular}

${ }^{11}$ All values represent mean $\pm \mathrm{SD}$.

${ }^{2)}$ Means with different letters $\left({ }^{--5}\right)$ with in a column are significantly different $(\mathrm{p}<0.05)$.

Table 8. Changes of general components (\%) in dried Grifola frondosa by different drying methods

\begin{tabular}{|c|c|c|c|c|c|}
\hline \multirow{2}{*}{\multicolumn{2}{|c|}{ Drying methods }} & \multicolumn{4}{|c|}{ Grifola frondosa } \\
\hline & & Moisture & Protein & Fat & Ash \\
\hline \multicolumn{2}{|l|}{ Control } & $90.32 \pm 0.53^{1222)}$ & $2.90 \pm 0.11^{\mathrm{f}}$ & $0.27 \pm 0.06^{\mathrm{C}}$ & $0.93 \pm 0.03^{f}$ \\
\hline \multicolumn{2}{|l|}{ Sun-drying } & $11.02 \pm 0.12^{\text {ef }}$ & $30.35 \pm 0.39^{b}$ & $1.92 \pm 0.25^{b}$ & $8.40 \pm 0.10^{b}$ \\
\hline \multirow{3}{*}{ Hot-air drying } & 40 & $11.79 \pm 0.41^{\mathrm{cd}}$ & $28.32 \pm 0.72^{d}$ & $2.03 \pm 0.05^{b}$ & $7.60 \pm 0.13^{\mathrm{d}}$ \\
\hline & 50 & $11.31 \pm 0.79^{\text {ef }}$ & $26.85 \pm 0.30^{\circ}$ & $2.13 \pm 0.08^{\mathrm{b}}$ & $7.12 \pm 0.34^{\mathrm{e}}$ \\
\hline & 60 & $11.48 \pm 0.25^{\mathrm{de}}$ & $27.81 \pm 0.11^{\mathrm{d}}$ & $1.96 \pm 0.07^{b}$ & $8.02 \pm 0.18^{\mathrm{c}}$ \\
\hline \multirow{3}{*}{ Low temperature vacuum drying } & 20 & $10.98 \pm 0.16^{f}$ & $28.23 \pm 0.66^{\mathrm{d}}$ & $2.13 \pm 0.08^{b}$ & $7.75 \pm 0.10^{\text {cd }}$ \\
\hline & 25 & $11.93 \pm 0.79^{c}$ & $29.16 \pm 0.24^{c}$ & $2.10 \pm 0.09^{b}$ & $8.83 \pm 0.05^{\mathrm{a}}$ \\
\hline & 30 & $11.11 \pm 0.66^{\mathrm{ef}}$ & $26.63 \pm 0.18^{\mathrm{e}}$ & $1.98 \pm 0.17^{\mathrm{b}}$ & $8.52 \pm 0.14^{\mathrm{ab}}$ \\
\hline \multirow{3}{*}{ Heat pump dehumidifying drying } & 30 & $11.32 \pm 0.18^{\text {ef }}$ & $26.85 \pm 0.10^{e}$ & $1.88 \pm 0.07^{b}$ & $7.90 \pm 0.52^{\text {cd }}$ \\
\hline & 40 & $12.69 \pm 0.36^{b}$ & $32.66 \pm 0.47^{\mathrm{a}}$ & $2.08 \pm 0.03^{b}$ & $7.00 \pm 0.09^{e}$ \\
\hline & 50 & $11.14 \pm 0.12^{\mathrm{ef}}$ & $33.07 \pm 0.24^{\mathrm{a}}$ & $2.44 \pm 0.31^{\mathrm{a}}$ & $7.00 \pm 0.09^{\mathrm{e}}$ \\
\hline \multicolumn{2}{|l|}{ Freeze drying } & $11.11 \pm 0.17^{\mathrm{ef}}$ & $32.81 \pm 0.06^{\mathrm{a}}$ & $2.06 \pm 0.11^{\mathrm{b}}$ & $6.82 \pm 0.09^{e}$ \\
\hline
\end{tabular}

\footnotetext{
${ }^{1)}$ All values represent mean \pm SD.

${ }^{2)}$ Means with different letters $\left({ }^{a f}\right)$ with in a column are significantly different $(\mathrm{p}<0.05)$.
} 
버섯의 베타글루칸 함량은 Table 9에 나타내었다. 새송이버 섯은 $28.29-39.39 \%$, 이슬송이는 $23.05-29.48 \%$, 잎새버섯은 $16.10-24.51 \%$ 의 베타글루칸 함량으로 나타났다. 새송이버 섯은 저온진공건조 $25^{\circ} \mathrm{C}$ 에서 $28.29 \%$ 로 가장 낮은 함량을 보였으며, 동결건조에서 $39.39 \%$ 로 베타글루칸의 함량이 가장 높게 나타났다. 이슬송이는 저온진공건조 $30^{\circ} \mathrm{C}$ 에서 $23.05 \%$ 로 가장 낮은 함량을 보였으며, 동결건조에서 $29.48 \%$ 로 가장 높게 나타났다. 잎새버섯은 동결건조에서 $16.10 \%$ 로 가장 낮은 함량을 보였으며, 저온진공 $25^{\circ} \mathrm{C}$ 에서 가장 높게 나타났다. 베타글루칸 함량이 버섯 $100 \mathrm{~g}$ 당 새송 이버섯은 22-38 g, 표고버섯은 $22 \mathrm{~g}$, 잎새버섯은 $15-20 \mathrm{~g}$ 존재하는 것으로 알려져 있으며 건조방법에 따른 베타글루 칸 함량을 분석한 결과 유사하게 나타났다 $(26,27)$.

Table 9. Changes of general $\beta$-glucan (\%) in dried mushroom by different drying methods

\begin{tabular}{|c|c|c|c|c|}
\hline \multirow{2}{*}{\multicolumn{2}{|c|}{$\begin{array}{c}\text { Drying methods } \\
\text { Control }\end{array}$}} & \multicolumn{3}{|c|}{ Pleurotus eryngii Lentinula edodes Grifola frondosa } \\
\hline & & $2.38 \pm 0.02^{1)}$ & $2.84 \pm 0.05$ & $2.68 \pm 0.01$ \\
\hline \multicolumn{2}{|l|}{ Sun-drying } & $32.41 \pm 0.71$ & $28.91 \pm 0.58$ & $18.71 \pm 0.12$ \\
\hline \multirow{3}{*}{ Hot-air drying } & 40 & $29.94 \pm 0.15$ & $24.74 \pm 0.58$ & $22.93 \pm 0.06$ \\
\hline & 50 & $35.38 \pm 0.13$ & $24.95 \pm 0.56$ & $21.45 \pm 0.20$ \\
\hline & 60 & $33.49 \pm 0.14$ & $24.72 \pm 0.06$ & $21.58 \pm 0.03$ \\
\hline \multirow{3}{*}{$\begin{array}{l}\text { Low temperature } \\
\text { vacuum drying }\end{array}$} & 20 & $31.87 \pm 0.90$ & $28.24 \pm 0.53$ & $21.36 \pm 0.34$ \\
\hline & 25 & $28.29 \pm 0.65$ & $27.09 \pm 0.53$ & $24.51 \pm 0.01$ \\
\hline & 30 & $35.19 \pm 0.42$ & $23.05 \pm 0.39$ & $20.19 \pm 0.30$ \\
\hline \multirow{3}{*}{$\begin{array}{l}\text { Heat pump } \\
\text { dehumidifying } \\
\text { drying }\end{array}$} & 30 & $32.73 \pm 0.42$ & $26.43 \pm 0.42$ & $18.92 \pm 0.05$ \\
\hline & 40 & $30.47 \pm 0.06$ & $28.72 \pm 0.21$ & $18.90 \pm 0.19$ \\
\hline & 50 & $31.90 \pm 0.87$ & $28.83 \pm 0.10$ & $18.90 \pm 0.20$ \\
\hline \multicolumn{2}{|l|}{ Freeze drying } & $39.39 \pm 0.27$ & $29.48 \pm 0.53$ & $16.10 \pm 0.16$ \\
\hline
\end{tabular}

${ }^{1)}$ All values represent mean $\pm \mathrm{SD}$.

\section{요 약}

새송이버섯(pleurotus eryngii), 이슬송이버섯(Lentinula edodes GNAO1), 잎새버섯(Grifola frondosa)을 천일건조, 열 풍건조 $\left(40,50,60^{\circ} \mathrm{C}\right)$, 저온진공건조 $\left(20,25,30^{\circ} \mathrm{C}\right)$, 히트펌프 제습건조 $\left(30,40,50^{\circ} \mathrm{C}\right)$ 및 동결건조를 한 후 건조조건과 건조방법에 따른 색도, 갈변도, 경도, 일반성분, 베타글루칸 등의 품질변화에 미치는 영향을 조사하였다. 색도 $\left(\mathrm{L}^{*}, \mathrm{a}^{*}\right.$, $\left.\mathrm{b}^{*}\right)$ 는 새송이버섯에서는 생버섯과 비교하여 동결건조에서 변화가 가장 적었으며, 이슬송이는 다른 건조방법에 비해 저온진공건조가 변화가 가장 적었다. 잎새버섯은 건조 시 다른 버섯보다 대조구에 비해 명도가 낮은 결과를 보였다. 갈변도는 건조조건 및 방법에 따른 차이가 있었으며, 전체 적으로 저온진공건조에서 온도가 높아질수록 감소하는 반
면, 히트험프제습건조는 온도가 높아질수록 증가하는 것으 로 나타났다. 경도는 새송이버섯의 경우 열풍건조, 저온진 공건조, 히트펌프습건조시 온도가 높아질수록 증가하는 것 으로 나타났으며, 이슬송이버섯은 열풍건조와 히트펌프제 습건조 하였을 때 온도가 높아질수록 증가하는 경향을 보였 다. 버섯의 베타글루칸 함량은 새송이버섯은 28.29-39.39\%, 이슬송이는 23.05-29.48\%, 잎새버섯은 $16.10-24.51 \%$ 로서 건조방법에 따른 차이를 보였다. 이상의 결과 이화학적, 기능적 품질분석을 고려해보았을 때 새송이버섯은 동결건 조, 이슬송이버섯은 $30^{\circ} \mathrm{C}$ 진공저온건조, 잎새버섯은 $50^{\circ} \mathrm{C}$ 열풍건조시 품질특성이 좋으며, 육안으로도 색상의 변화가 적어 소비자의 기호성에 적합할 것으로 사료된다.

\section{References}

1. Rajarathnam S, Bano Z (1987) Pleurotus mushrooms. Part1. A morphology, life cycle, taxonomy, breeding and cultivation. Crit Rev Food Sci Nutr, 26, 157-222

2. Eger G (1978) Biology and breeding of Pleurotus, in The Biology and Cultivation of edible Mushroom. AcademicPress, NY, USA, p 78-92

3. Jin SK, Kim IS, Kim DH, Jeong KJ, Moon SS (2006) Effect of Pleurotus eryngii and meat particle size on sausage quality. Korean J Food Sci Anim Resour, 26, 343-348

4. Kim YS (1998) Quality of wet noodle prepared with wheat flour and mushroom powder. Korean J Food Sci Technol, 30, 1373-1380

5. Jang HL, Lee JH, Hwang MJ, Choi Y, Kim H, Hwang J, Nam JS (2015) Comparison of physicochemical properties and antioxidant activities between Lentinula edodes and new cultivar Lentinula edodes GNA01. J Korean Soc Food Sci Nutr, 44, 1484-1491

6. Kim Y (2011) Novel strain of Lentinula edodes GNA01. USA patent NO. 13,994,696

7. Suzuki S, Oshima S (1976) Influence of shiitake (Lentinus edodes) on human serum cholesterol. Mushroom Sci, 9, 463-467

8. Jong SC, Birmingham JM (1993) Medicinal and therapeutic value of the shiitake mushroom. Adv Appl Microbiol, 39, 153-184

9. Wu MJ, Cheng TL, Cheng SY, Lian TW, Wang L, Chiou SY (2006) Immunomodulatory properties of Grifola frondosa in submerged culture. J Agric Food Chem, 54, 2906-2914

10. Kodama N, Murata Y, Asakawa A, Inui A, Hayashi M, 
Sakai N, Nanba H (2005) Maitake D-fraction enhances antitumor effects and reduces immunosuppression by mitomycin-C in tumor-bearing mice. Nutrition, 21, 624-629

11. Talpur NA, Echard BW, Fan AY, Jaffari O, Bagchi D, Preuss HG (2002) Antihypertensive and metabolic effects of whole maitake mushroom powder and its fractions in two rat strains. Mol Cell Biochem, 237, 129-136

12. Fukushima M, Ohashi T, Fujiwara Y, Sonoyama K, Nakano M (2001) Cholesterol-lowering effects of maitake (Grifola frondosa) fiber, shitake (Lentinus edodes) fiber, and enokitake (Flammulina velutipes) fiber in rats. Exp Biol Med, 226, 758-765

13. Mau JH, Lin HC, Song SF (2002) Antioxidant properties of several specialty mushrooms. Food Res Int, 35, 519-526

14. Manzi P, Gambelli L, Marconi S, Vivanti V, Pizzoferrato L (1999) Nutrients in edible mushrooms: an inter-species comparative study. Food Chem, 65, 477-482

15. Holdsworth SD (1971) Dehydration of food products. J Food Technol, 6, 331-334

16. Matser AM, Knott ER, Teunissen PGM, Bartels PV (2000) Effects of high isostatic pressure on mushrooms. J Food Eng, 45, 11-16

17. Hiraide M, Miyazaki Y, Shibata Y (2004) The smell and odorous components of dried shiitake mushroom, Lentinula edodes I: relationship between sensory evaluations and amounts of odorous components. J Wood Sci, 50, 358-364

18. AOAC (1997) Official methods of analysis. $16^{\text {th }}$ ed. Association of Official Analytical Chemists (No. 934.06), Arlington, VA, USA

19. Ha YS, Park JW, Lee JH (2001) Physical characteristics of mushroom (Agaricus bisporus) as influenced by different drying methods. Korean J Food Sci Technol, 33, 245-251

20. Choi SR, Yu YJ, Ahn MS, Song EJ, Seo SY, Choi MK, Han HA, Song YJ, Kim HJ, So SY, Lee GK, Kim CK (2014) Quality characteristics by various drying methods in ear mushroom (Auricularia auricula-judae Quel.). Korean J Med Crop Sci, 22, 497-503

21. Jee JH, Lee HD, Chung SK, Choi JU (1999) Changes in color value and chemical components of hoelen by various drying methods. Korean J Food Sci Technol, 31, 575-580

22. Park JD, Kang HA, Chang KS (1996) Hot air drying characteristics of oak mushroom (Lentinus edodes) by microcomputer control system. Korean J Food Sci Technol, 28, 72-76

23. Qi LL, Zhang M, Mujumdar AS, Meng XY, Chen HZ (2014) Comparison of drying characteristics and quality of shiitake mushrooms (Lentinus edodes) using different drying methods. Drying Technol, 32, 1751-1761

24. Jin TY, Oh JD and Eun JB (2006) Change of physicochemical characteristics and functional compoments in the raw materials of Saengsik, Uncooked food by drying methods. Korean J Food Sci Technol, 38, 188-196

25. Rajarathnam S, Shashirekha MN, Bano Z (1998) Biodegradative and biosynthetic capacities of mushrooms: present and future strategies. Crit Rev Biotechnol, 18, 91-236

26. Manzi P, Pizzoferrato L (2000) Beta-glucans in edible mushrooms. Food Chem, 68, 315-318

27. Um SN, Jin GE, Park KW, YU YB, Park KM (2010) Physiological activity and nutritional composition of Pleurotus species. Korean J Food Sci Technol, 42, 90-96 